\title{
Neuroendocrine tumor of the appendix: Twelve years of results from a single institution
}

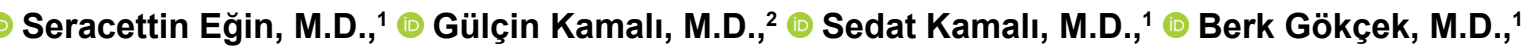

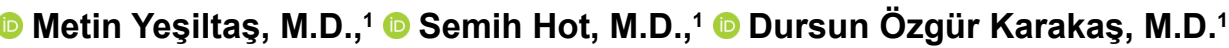

\begin{abstract}
1Department of General Surgery, University of Health Sciences, Okmeydanı Training and Research Hospital, İstanbul-Turkey ${ }^{2}$ Department of Pathology, University of Health Sciences, Okmeydanı Training and Research Hospital, İstanbul-Turkey
\end{abstract}

\begin{abstract}
BACKGROUND: The aim of this study was to investigate the incidence of appendiceal neuroendocrine tumors (NET) in an acute appendicitis cohort, as well as to investigate the behavioral form of the tumor. Our secondary aim was to investigate survival in patients with appendiceal NET.

METHODS: Between February 2006 and June 2018, 65I8 appendectomies were performed for acute appendicitis in the department of surgery, University of Health Sciences, Okmeydanı Education and Research Hospital, İstanbul, Turkey. The medical records of these consecutive 6518 appendectomy patients were evaluated retrospectively. After the histopathological analysis, a total of 22 patients were identified as cases of appendiceal NET. These patients were included in the study. A retrospective analysis of data including gender, age, intraoperative surgical findings, duration of postoperative follow-up and survival, tumor localization, the diameter of the tumor, tumor grade, invasion, surgical margin, and stage of the tumor was performed.
\end{abstract}

RESULTS: The incidence of appendiceal NET was $0.33 \%$. Eleven patients were diagnosed as primary pathological stage pTIaNOM0 according to the European Neuroendocrine Tumor Society guidelines. One patient was diagnosed as primary pathological stage PTIbNOM0, and 10 patients were diagnosed as primary pathological stage PT2NOM0. The median tumor diameter was $7.6 \mathrm{~mm}$. There was no patient with a tumor diameter greater than $20 \mathrm{~mm}$.

CONCLUSION: The incidence of appendiceal NET in our study is consistent with that stated in the literature. The results of our research suggest that further surgical procedures for NETs that occur coincidentally in patients of the AA cohort are often unnecessary. In addition, the study revealed that disease-free survival (100\%) was good over a mean follow-up of 59.2 months.

Keywords: Appendicitis; appendix; neuroendocrine tumor; World Health Organization.

\section{INTRODUCTION}

Neuroendocrine tumors (NETs), formerly referred to as carcinoid tumors, which can be seen everywhere where neuroendocrine cells are present, are the most common tumors of the appendix. ${ }^{[l]}$ Other primary appendiceal neoplasm histopathology include adenocarcinomas, mucinous neoplasms, and goblet cell carcinoids. ${ }^{[2]}$ The annual incidence of appendiceal NET is $0.15-0.6$ per 100,000 individuals. They are seen slightly more often in female than in male patients at an average age of $40-50$ years. Appendiceal NET is seen in- cidentally during appendectomy with a rate of approximately 3-5 patients per 1000 appendectomies..$^{[3]}$ The ENETS Consensus Guidelines for NET of the Appendix concluded that an appendiceal NET $<I \mathrm{~cm}$, with invasion up to the subserosa or mesoappendiceal invasion up to $3 \mathrm{~mm}$ and clear surgical margins, poses no further risk of recurrence after an appendectomy. Most of these tumors (70\%) arise from the tip of the appendix. Tumors at the base of the appendix, tumors of $\mathrm{I}-2 \mathrm{~cm}$ in diameter, and tumors with deep mesoappendiceal invasion or margin invasion present a relevant risk of recurrence. In these tumors, further surgical procedures are

Cite this article as: Eğin S, Kamalı G, Kamalı S, Gökçek B, Yeşiltaş M, Hot S, et al. Neuroendocrine tumor of the appendix: Twelve years of results from a single institution. Ulus Travma Acil Cerrahi Derg 2019;25:118-122.

Address for correspondence: Seracettin Eğin, M.D.

SBÜ Okmeydanı Eğitim ve Araştırma Hastanesi, Genel Cerrahi Kliniği, İstanbul, Turkey.

Tel: +90 212 - 3145555 E-mail: seracettin_egin@hotmail.com

Ulus Travma Acil Cerrahi Derg 2019;25(2):118-122 DOI: 10.14744/tjtes.2019.38283 Submitted: 19.11.2018 Accepted: 12.02.2019 Online: I4.03.2019

Copyright 2019 Turkish Association of Trauma and Emergency Surgery 
needed, although no data have literally proven the survival benefit of more aggressive surgery. ${ }^{[3]}$ The mean age of appendiceal NET at diagnosis has been reported to be between 38 and $5 \mathrm{I}$ years. ${ }^{[4,5]}$

Appendiceal NET is rarely symptomatic in most of the cases because of the incidental nature of their diagnosis. Abdominal pain, mass effect, or symptoms of bowel obstruction may be seen in patients with an extensive local disease or distant metastases. An association with the carcinoid syndrome is an extremely exceptional event in patients with metastasis and probably associated with an intestinal primary tumor. ${ }^{[3]}$

The aim of the present study was to investigate the incidence of appendiceal NET in an acute appendicitis cohort with laparoscopic or conventional appendectomy. We also aimed to investigate the behavioral form of the tumor by revealing its spreading characteristics, such as size, World Health Organization (WHO) 2010 classification grading, invasion, surgical margin, and TNM stage of the tumor. Our secondary aim was to investigate survival in patients with appendiceal NET. We think that even small databases will be useful in the treatment of appendiceal NET because most general surgeons infrequently encounter this problem in clinical practice.

\section{MATERIALS AND METHODS}

The study was approved by the ethics committee of Okmeydanı Education and Research Hospital, Istanbul, Turkey. A total of 6518 appendectomies with a diagnosis of acute appendicitis between February 2006 and June 2018 in the Department of Surgery, University of Health Sciences, Okmeydanı Education and Research Hospital, Istanbul, Turkey were performed. The medical records of these consecutive 6518 patients with appendectomy were evaluated retrospectively. After the histopathological analysis of appendectomy specimens, a total of 22 patients were identified as appendiceal NET and were included in the study. Patients with other appendiceal benign and malignant tumors were excluded from the study.

A retrospective database including gender, age, intraoperative surgical findings, duration of postoperative follow-up and
Table I. Characteristics of 22 patients with appendiceal NET

\begin{tabular}{lc} 
Incidence at diagnosis (according to & \\
appendectomy) & $0.33 \%$ \\
Gender rate (female/male) & $10 / 12$ \\
Median age (age limits/years) & 32.5 (I7-57) \\
Clinical appearance & Acute appendicitis \\
Primary surgical procedure & Appendectomy \\
Secondary surgical procedure & Not needed \\
Mean follow-up duration & \\
(follow-up limits/months) & $59.2(3-138)$ \\
\hline
\end{tabular}

NET: Neuroendocrine tumors

survival, tumor localization, diameters of the tumors, tumor WHO grades, invasion, surgical margin, and TNM stage of the tumor was obtained. The final pathology reports on day 15 after surgery were obtained. If NET was detected in the pathology report, the patient was called via phone for followup on months 6 and 12 after surgery and then annually.

\section{RESULTS}

Appendiceal NETs were determined in 22 out of 6518 patients with an incidence of $0.33 \%$. Of the 22 patients, 10 were females, and 12 were males. The median age of this group was 32.5 years (Table I). The age distribution of 22 patients with NETs is shown in Figure la.

Of the 22 patients, 14 were only diagnosed by ultrasound and clinical examination, and others were by abdominal computed tomography (CT). As a result, all cases were diagnosed as acute appendicitis preoperatively. There were no any pathological signs diagnosed for NETs on both abdominal ultrasonography and CT scan. Appendectomy was performed for all cases. Six patients underwent laparoscopic surgery, whereas all the other patients underwent conventional surgery. The distribution of intraoperative staging was 10 catarrhal, 9 phlegmonous, and 3 gangrenous stages, respectively. There was no perforated appendicitis in any pa-
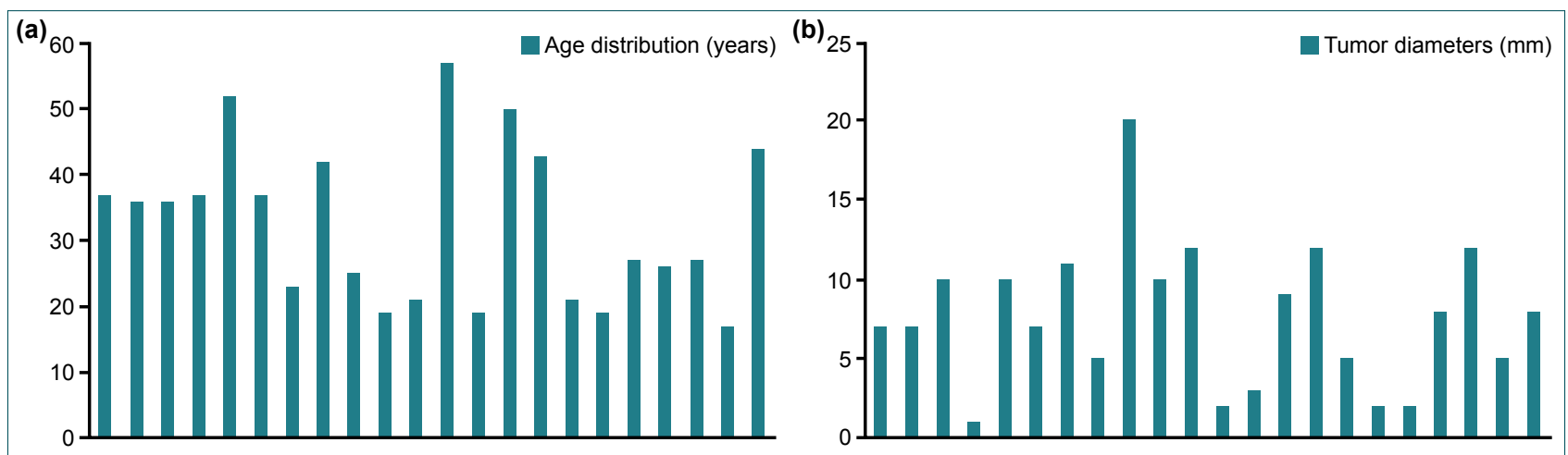

Figure 1. (a) Age distribution of patients with neuroendocrine tumors. (b) Tumor diameters of neuroendocrine tumors. 
tients. There were no any suspicious signs diagnosed intraoperatively for NETs.

The final pathological diagnosis of these patients was NET. In 19 out of 22 patients, the final pathological diagnosis was GI well-differentiated NET according to the WHO 2010 recommendation (Table 2). ${ }^{[6]}$ In all the other patients, the final pathological diagnosis was G2 well-differentiated NET. Eleven patients were diagnosed as primary pathological stage PTIaNOMO according to the European Neuroendocrine Tumor Society (ENETS) guidelines. ${ }^{[3]}$ In addition, I patient was diagnosed as primary pathological stage PTIbNOMO, and 10 patients were diagnosed as primary pathological stage PT2N0M0. All pathological findings are summarized in Table 2.

The median tumor diameter was $7.6 \mathrm{~mm}$ (Table 2). Only one case had a tumor diameter of $20 \mathrm{~mm}$. Seventeen patients had a tumor diameter of $\leq 10 \mathrm{~mm}$. Five patients had a tumor diameter of I I-20 mm. There was no any patient with a tumor diameter wider than $20 \mathrm{~mm}$ (Fig. Ib). Surgical margins were

Table 2. Histopathological characteristics of 22 patients with appendiceal NET

\begin{tabular}{|c|c|}
\hline \multicolumn{2}{|l|}{ Tumor localization, $n$ (\%) } \\
\hline I/3 distal & $18(81.8)$ \\
\hline I/3 middle & $4(18.2)$ \\
\hline Mean tumor diameter (diameter limits) & $7.6 \mathrm{~mm}(\mathrm{I}-20 \mathrm{~mm})$ \\
\hline \multicolumn{2}{|l|}{$\mathrm{Ki}-67$ proliferative index and } \\
\hline \multicolumn{2}{|l|}{ WHO 2010 classification, n (\%) } \\
\hline$\leq 2 \% \mathrm{Gl}$ & $19(86.4)$ \\
\hline $3-20 \%$ G2 & $3(13.6)$ \\
\hline$>20 \% \mathrm{G} 3$ & 0 \\
\hline \multicolumn{2}{|l|}{ Tumor infiltration, n (\%) } \\
\hline Infiltration of the submucosa & $3(13.6)$ \\
\hline Infiltration of the muscularis propria & $9(40.9)$ \\
\hline Infiltration of the subserosa & $4(18.2)$ \\
\hline Infiltration of the mesoappendix & $6(27.3)$ \\
\hline \multirow{2}{*}{\multicolumn{2}{|c|}{$\begin{array}{l}\text { TNM staging according to the ENETS } \\
\text { guidelines, } n(\%)\end{array}$}} \\
\hline & \\
\hline Tla No Mo & II (50) \\
\hline TIb NO MO & I (4.5) \\
\hline T2 No MO & $10(45.5)$ \\
\hline \multicolumn{2}{|l|}{ Lymphovascular invasion, n (\%) } \\
\hline Positive & I (4.5) \\
\hline Negative & $21(95.5)$ \\
\hline \multicolumn{2}{|l|}{ Surgical margin, $n(\%)$} \\
\hline Positive & 0 \\
\hline Negative & $22(100)$ \\
\hline
\end{tabular}

NET: Neuroendocrine tumors; WHO: World Health Organization; TNM: Tumor-node-metastasis; ENETS: European Neuroendocrine Tumor Society. negative in all patients. Therefore, any secondary surgical procedure was not suggested. There were no any pathological signs in control colonoscopies of appendiceal NETs on postoperative months 6 and 12 . In all patients, mean follow-up duration was 59.2 months (Table I). Thus far, all patients are disease free and are alive.

\section{DISCUSSION}

This appendectomy cohort is one of the largest in current studies on appendiceal NETs. In our study, the incidence of NET in patients with immediate appendectomy $(0.33 \%)$ is consistent with the literature $(0.3 \%-0.5 \%){ }^{[3]}$ The mean age of 32.5 years was lower than that of 38-5I years reported in the literature. ${ }^{[4,5]}$ As seen in Figure la, the mean age of the patients was low because the mean age of II patients in our study was lower than the mean age.

Appendectomy is an adequate treatment for NETs with a tumor diameter of $<10 \mathrm{~mm}$. A secondary surgical procedure is not needed for these tumors. Right hemicolectomy is recommended for tumors with a diameter of $>20 \mathrm{~mm}$, but optimal treatment for tumors with a diameter of $10-20 \mathrm{~mm}$ is still controversial. ${ }^{[3]}$ In the present study, appendectomy was regarded as an adequate treatment for all appendiceal NETs. Since all NETs were smaller than $20 \mathrm{~mm}$, the Ki-67 index ratios were between $0 \%$ and $9.5 \%$, and the tumors were welldifferentiated $\mathrm{GI}$ and $\mathrm{G} 2$ according to the WHO grading. Moreover, regional lymph nodes and distant metastases were not found; surgical margins were negative, and TNM staging according to the ENETS guidelines was at most T2NOMO. For this reason, we did not recommend secondary surgical procedures and wider resections for grade I and 2 NETs. Nevertheless, Raoof et al. ${ }^{[1]}$ suggested that the probability of nodal metastases is $2.7 \%$ in tumors with a diameter of $\leq 10$ $\mathrm{mm}, 31 \%$ in tumors with a diameter of $\mathrm{II}-20 \mathrm{~mm}$, and $64 \%$ in tumors with a diameter of $>20 \mathrm{~mm}$. They thought that lymph node count is a prognostic factor for well-differentiated NETs.

In the present study, it was decided according to the ENETS guideline whether a second surgical intervention is needed. [3] The therapeutic algorithm suggested for small $(<20 \mathrm{~mm})$ appendiceal NET was followed. RO resection was performed for all patients. The mesoappendix infiltration reported for six patients was $<3 \mathrm{~mm}$. All appendiceal NETs were found in either 1/3 distal or 1/3 middle (Table 2). No patient had a NET localized to the base of the appendix. Risk factors were lymphovascular invasion and $\mathrm{G} 2$, and 18 patients had no risk factors (Table 2). Treatment was completed for these 18 patients (no risk factors, RO resection, tumors localized in distal or middle, TI or T2 tumors, tumor size $<20 \mathrm{~mm}$ ). Lymphovascular invasion from risk factors was reported for only a 27-year-old patient. G2 from the other risk factors was reported for three patients (Table 2). The three patients were 21-, 23-, and 43-year-old patients, respectively. According to 
the ENETS guideline, discussion about right-sided hemicolectomy is recommended for these four patients with risk factors. We decided to follow up these four patients by taking into account their ages and other reasons. In the follow-up period, no recurrence or metastasis due to appendiceal NET was detected until the end of the present study. Therefore, we did not perform right-sided hemicolectomy for these four patients with risk factors.

Most general surgeons do not recognize appendiceal NETs at preoperative radiological examination and during surgery because appendiceal NETs are usually diagnosed as acute appendicitis. For this reason, if there is no any pathological sign of appendiceal NET at radiological diagnosis or during operation, we suggest that appendectomy is a sufficient treatment because most patients do not need additional treatment. Any postoperative diagnostic procedure is not required for patients with well-differentiated NET with a maximum diameter of $\left\langle 1 \mathrm{~cm}\right.$ and $\mathrm{RO}$ resection. ${ }^{[3]}$ Abdominal $\mathrm{CT}$ or $\mathrm{MR}$ to eliminate the probability of lymph node or distant metastasis may be recommended even though there are no clear data for well-differentiated NETs with a diameter of I-2 $\mathrm{cm}$ and RO resection. ${ }^{[3]}$ Abdominal CT or MR and somatostatin receptor imaging (somatostatin receptor scintigraphy or somatostatin receptor-PET/CT) should be performed in patients with deep mesoappendiceal infiltration or angioinvasion and tumors $>2 \mathrm{~cm} \cdot{ }^{[3]}$ Although chromogranin $A$ has not been especially confirmed for diagnosis and follow-up of appendiceal NET, it may be utilized as a tumor marker in advanced metastatic appendiceal NET. ${ }^{[3]}$

A well-differentiated appendiceal NET $<2 \mathrm{~cm}$ is treated by appendectomy independent of the location of the tumor. Right hemicolectomy is recommended in NETs measuring $\mathrm{I}-2 \mathrm{~cm}$ with positive tumor margins or with mesoappendiceal invasion (ENETS T2), higher proliferation rate (G2), and positive vascular invasion. NETs with a diameter of $>2 \mathrm{~cm}$ should be cured by right hemicolectomy. These issues are minimal consensus statements on the surgical therapy of NETs according to the ENETS Consensus Guidelines 2016. ${ }^{[3]}$ We approve the statements of this guideline as well. We properly treated our NET cases according to the statements of this guideline.

For follow-up strategies, it should comply with the ENETS Consensus Guidelines for the Standards of Care in NETs [8]. Since this was a cohort study, we followed all patients with NET on months 6 and 12 after surgery and then annually. Since the importance of their disease was well-described to 22 patients, all patients came to the control examination after 6 and 12 months of surgery. For follow-up of patients with appendiceal NET, they were reached by telephone when they did not come for their annual control examination. All patients survived in the follow-up period. The patients in the NET group were mostly young patients with a mean age of 32.5 years (Table I). The oldest patient was a 57 -year-old woman who was operated before only $I$ year at the end of the present study. Sixteen patients were $<40$ years old, and six patients were $>40$ years old (Fig. Ia). Mean follow-up duration was 59.2 months. The survival of the majority of appendiceal NET is excellent in the series, with lower tumor stages with 5 -year survival rates of $100 \%$ or close to this. ${ }^{[3]}$ No patient died due to NET in the mean follow-up period of 59.2 months because the patients in the present study had lower tumor stages. Furthermore, no patient died due to any other reason during the follow-up period. This may be due to the young age of the patients. Follow-up is not necessary for well-differentiated NETs of $\langle\mathrm{I} \mathrm{cm}$ and R0 resection. ${ }^{[7]}$ Most participants at the Consensus Conference did not recommend regular follow-up for well-differentiated NETs of $\mathrm{I}-2 \mathrm{~cm}$ and $\mathrm{RO}$ resection, but follow-up may be necessary for patients with risk factors. Nevertheless, a specific follow-up schedule is not suggested. ${ }^{[7]}$ All other NETs of $>2$ $\mathrm{cm}$, metastasis, and $\mathrm{RI}$ resection should be followed up at 6 and 12 months postoperatively and then annually. However, this approach has also not been confirmed. ${ }^{[7]}$

The search for appendiceal NETs in a single-center and long-term widest appendectomy cohort in the literature is a strong direction of the present study. The lack of a further stage ENETS T2 is a weakness of our study. Since appendiceal NETs are usually presented in the early stages with clinical signs of acute appendicitis, advanced stage tumors are quite rare. Therefore, an appendiceal NET with a more advanced stage than ENETS T2 may not be found in the present study.

In conclusion, the incidence of appendiceal NET in the present study is consistent with the literature. The results of the study suggest that further surgical procedures for NETs that occur coincidentally in patients of acute appendicitis cohort are often unnecessary. In addition, the study suggests that disease-free survival (100\%) is good over a mean followup of 59.2 months. General surgeons encountering incidentally with early stage appendiceal NET (ENETS TI and T2) should not be concerned about therapy and prognosis.

\section{Conflict of interest: None declared.}

\section{REFERENCES}

1. Raoof M, Dumitra S, O'Leary MP, Singh G, Fong Y, Lee B. Mesenteric Lymphadenectomy in Well-Differentiated Appendiceal Neuroendocrine Tumors. Dis Colon Rectum 2017;60:674-81. [CrossRef]

2. Carr NJ, Cecil TD, Mohamed F, Sobin LH, Sugarbaker PH, GonzálezMoreno S, et al; Peritoneal Surface Oncology Group International. A Consensus for Classification and Pathologic Reporting of Pseudomyxoma Peritonei and Associated Appendiceal Neoplasia: The Results of the Peritoneal Surface Oncology Group International (PSOGI) Modified Delphi Process. Am J Surg Pathol 2016;40:14-26. [CrossRef]

3. Pape UF, Niederle B, Costa F, Gross D, Kelestimur F, Kianmanesh R, et al; Vienna Consensus Conference participants. ENETS Consensus Guidelines for Neuroendocrine Neoplasms of the Appendix (Excluding Goblet Cell Carcinomas). Neuroendocrinology 2016;103:144-52.

4. Ellis L, Shale MJ, Coleman MP. Carcinoid tumors of the gastrointesti- 
nal tract: trends in incidence in England since 1971. Am J Gastroenterol 2010;105:2563-9. [CrossRef]

5. Garcia-Carbonero R, Capdevila J, Crespo-Herrero G, Díaz-Pérez JA, Martínez Del Prado MP, Alonso Orduña V, et al. Incidence, patterns of care and prognostic factors for outcome of gastroenteropancreatic neuroendocrine tumors (GEP-NETs): results from the National Cancer Registry of Spain (RGETNE). Ann Oncol 2010;21:1794-803. [CrossRef]
6. Oberg K, Castellano D. Current knowledge on diagnosis and staging of neuroendocrine tumors. Cancer Metastasis Rev 2011;30 Suppl 1:3-7.

7. Arnold R, Chen YJ, Costa F, Falconi M, Gross D, Grossman AB, et al; Mallorca Consensus Conference participants; European Neuroendocrine Tumor Society. ENETS Consensus Guidelines for the Standards of Care in Neuroendocrine Tumors: follow-up and documentation. Neuroendocrinology 2009;90:227-33. [CrossRef]

\section{ORIJjINAL ÇALIŞMA - ÖZET}

\section{Apendiksin nöroendokrin tümörü: Bir kurumun 12 yıllık sonuçları \\ Dr. Seracettin Eğin, ${ }^{1}$ Dr. Gülçin Kamalı, ${ }^{2}$ Dr. Sedat Kamalı, ${ }^{1}$ Dr. Berk Gökçek, ${ }^{1}$ Dr. Metin Yeşiltaş, ${ }^{1}$ Dr. Semih Hot, ${ }^{1}$ Dr. Dursun Özgür Karakaş ${ }^{1}$}

'Sağıık Bilimleri Üniversitesi, Okmeydanı Eğitim ve Araştırma Hastanesi, Genel Cerrahi Kliniği, İstanbul

${ }^{2}$ Sağlık Bilimleri Üniversitesi, Okmeydanı Eğitim ve Araştırma Hastanesi, Patoloji Kliniği, İstanbul

AMAÇ: Akut apandisit tanısıyla apendektomi yapılan hasta topluluğunda apendiks nöroendokrin tümörlerinin (NET) görülme sıklığını ve tümörün davranış şeklini araştırmayı amaçladık. İkincil amacımız apandisiyel NET’li hastalarda sağkalımı araştırmaktır.

GEREÇ VE YÖNTEM: Şubat 2006-Haziran 2018 tarihleri arasında Sağlık Bilimleri Üniversitesi İstanbul Okmeydanı Eğitim ve Araştırma Hastanesi Genel Cerrahi Kliniği'nde akut apendisit tanısıyla 6518 apendektomi uygulandı. Bu ardışık 65 । 8 apendektomi hastasının tıbbi kayıtları geriye dönük olarak değerlendirildi. Histopatolojik analizlerden sonra toplam 22 hasta apendiks NET olarak tanımlandı. Bu hastalar çalışmaya dahil edildi. Cinsiyet, yaş, ameliyat sırasında cerrahi bulgular, ameliyat sonrası takip süresi ve sağkalım süresi, tümör lokalizasyonu, tümör çapları, tümör derecesi, invazyon, cerrahi sınır ve tümör evresi gibi geriye dönük bir veri tabanı elde edildi.

BULGULAR: Apendiks NET'lerinin görülme sıklığı \%0.33 idi. On bir hastaya Avrupa Nöroendokrin Tümör Derneği Kılavuzu'na göre primer patolojik evre PT IaNOMO tanısı konuldu. Ayrıca bir hastaya primer patolojik evre PTIbNOMO ve on hastaya primer patolojik evre pT2NOM0 tanısı konuldu. Ortalama tümör çapı $7.6 \mathrm{~mm}$ idi. Tümör çapı 20 mm'den daha büyük olan herhangi bir hasta yoktu.

TARTIŞMA: Çalışmadaki apendiks NET görülme sıklığı literatür ile uyumludur. Çalışmanın sonuçları akut apandisit hastalarında rastlantısal olarak ortaya çıkan NET'ler için daha ileri cerrahi işlemlerin gereksiz olduğunu göstermektedir. Buna ek olarak, çalışma hastalıksız sağkalımın (\% I00), ortalama 59.2 aylık takipte iyi olduğunu göstermektedir.

Anahtar sözcükler: Apendiks; apendisit; Dünya Sağlık Örgütü; nöroendokrin tümör.

Ulus Travma Acil Cerrahi Derg 2019;25(2):। 18-122 doi: 10.14744/tjtes.2019.38283 